UDK 637.5:006.83:664.91+577.115:577.112(497.11)

\title{
SODIUM CHLORIDE AND NITRITE CONTENTS IN CANNED MEAT IN PIECES FROM THE SERBIAN MARKET
}

Tatjana A. Peulic ${ }^{* 1}$, Predrag M. Ikonić ${ }^{1}$, Marija R. Jokanović ${ }^{2}$, Jovana D. Delić ${ }^{1}$, Jasmina M. Gubić ${ }^{1}$, Snežana B. Škaljac $^{2}$, Jasna S. Mastilović ${ }^{1}$

${ }^{1}$ University of Novi Sad, Institute of Food Technology, 21000 Novi Sad, Bulevar cara Lazara 1, Serbia

${ }^{2}$ University of Novi Sad, Faculty of Technology Novi Sad, 21000 Novi Sad, Bulevar cara Lazara 1, Serbia

\begin{abstract}
Canned meat in pieces (CM) is a group of meat products widely consumed by children and consumers with special diet regimes, due to high protein and low fat content. In this study safety of these products regarding sodium chloride and nitrite contents was examined in total of 19 meat samples produced by 14 most represented meat processors on Serbian market. The statement about high protein and low fat content in CM for products from the Serbian market was confirmed. The products made from chicken meat ("Pileća prsa", protein 12.4 to $17.4 \mathrm{~g} / 100 \mathrm{~g}$; fat 0.92 to 3.84 $\mathrm{g} / 100 \mathrm{~g}$ ) had higher protein and lower fat content that the products made from pork ("Pizza šunk", protein 11.5 to $14.3 \mathrm{~g} / 100 \mathrm{~g}$; fat 4.61 to $14.4 \mathrm{~g} / 100 \mathrm{~g}$ ). In the group "Pileća prsa" $90.91 \%$ of samples had sodium chloride content below $1.5 \mathrm{~g} / 100 \mathrm{~g}$, while in the group "Pizza šunka", 75\% of samples had sodium chloride content lower than $1.5 \mathrm{~g} / 100 \mathrm{~g}$. Residual nitrite content in product "Pileća prsa" ranged from 0.62 to $20.7 \mathrm{mg} / \mathrm{kg}$ and in product "Pizza šunka" this content ranged from 3.27 to $19.2 \mathrm{mg} / \mathrm{kg}$. These results indicate that all analysed samples were below the required limits of nitrite content. According to the results obtained in this study, children and consumers with special diet regimes are free to consume Serbian meat products in the type of CM considering the contents of protein and fat, as well as sodium chloride and nitrite residue.
\end{abstract}

Key words: meat products, pork, chicken, protein content, fat content, safety, Serbian meat product market

\section{INTRODUCTION}

Meat and meat products are widely consumed in Serbia. The main reason for meat consumption is high quality proteins with high content of essential amino acids. Moreover, meat is a valuable source of vitamin B12, zinc, phosphorous and iron, but low in carbohydrates (Rede \& Petrovic, 1997; Lawrie \& Ledward, 2006; Godfray et al., 2018). On the other hand, high content of fat, rich in saturated fatty acids in some meat and meat products, can be a problem for consumers suffering from cardiovascular diseases and other illnesses.

Thus canned meat in pieces (CM) is widely consumed by children and consumers with special diet regimes, due to high protein and low fat content. But, the question is how high is the content of sodium chloride and nitrite in this type of product? Sodium chloride is a widely 
used preservative in meat processing industry, since it has influence on safety and quality parameters of meat products. It plays a great role in microbial stability by controlling the growth of foodborne pathogens and spoilage microorganisms. Also, sodium chloride improves the sensory properties by enhancing the perception of meat flavour, textural properties and colour (Desmond, 2006; Vuković, 2012; Wu et al., 2015; Pretorius and Schönfeldt, 2018; Silva Haddada et al., 2018). Apart from important role in meat products safety and quality, sodium chloride plays an important role in the human body. But, the excessive intake of sodium contribute to high blood pressure and increase the risk of heart disease and stroke, as well as other health problems such as stomach cancer and renal diseases (Doyle \& Glass, 2010; WHO, 2010; Haizhou et al., 2015; WHO, 2016). Therefore, many countries try to regulate total sodium chloride intake through national strategies (Aaslyng et al., 2014; Inguglia et al., 2017). Food Standards Agency (FSA), World Health Organization (WHO), European Food Safety Authority (EFSA) and other regulatory authorities recommend a daily average consumption of $<5-6 \mathrm{~g}$ of $\mathrm{NaCl}$ or $<2-2.4 \mathrm{~g}$ of $\mathrm{Na}$ (Matthews and Strong, 2005; Desmond, 2006; EFSA, 2009; WHO, 2012). Since meat products are generally recognized as the most responsible for sodium chloride intake it would be desirable to consider all the possibilities for sodium chloride reduction in these products, going toward recommendations of health authorities (Kamenik et al., 2017).

Nitrite is also widely used in meat processing industry as an additive due to its inhibitory role in the growth of foodborne pathogens and spoilage microorganisms, as well as due to its antioxidant action against lipid oxidation (Barbieri, Bergamaschi, Barbieri, \& Franceschini, 2012; Vuković, 2012; Sebranek, 2009). Like sodium chloride, nitrite also improves the sensory properties of meat products by forming the unique pink colour, flavour and aroma (Honikel, 2008; Parthasarathy \& Bryan, 2012; Vuković). The content of added nitrite for meat products is defined by the Commission Regulation (EU) No. 1129/2011 and the Serbian Regulation 53/2018. Apart from the mentioned positive effects of nitrite, the use of nitrite could lead to the formation of carcinogenic nitrosamines, some acute and chronic toxicities such as methemoglobinemia, thyroid disorders and increased risks of gastric, oesophageal, nasopharyngeal and bladder cancers (Sun, Mi, Lee, Shin, \& Sung, 2007; Gilchrist et al., 2010; EFSA, 2010; Zhang et al., 2018).

Taking into account the above mentioned considerations and before making decisions for further reduction of sodium chloride and nitrite contents in CM products it is necessary to determine their real levels in the final products. Thus, the main aim of this study was to investigate sodium chloride and nitrite contents in $\mathrm{CM}$ products, produced by the most represented meat processors on the Serbian market.

\section{MATERIALS AND METHODS}

\section{Meat product samples}

Total of 19 meat samples produced by 14 most represented meat processors (P1-P14) were collected from the Serbian retail market during the year 2018. The collected samples belonged to CM group of meat products as defined by the Serbian Regulations 94/15, 104/15 and 19/17. Eleven samples $(\mathrm{n}=11)$ were made from chicken meat („Pileća prsa") and eight samples $(\mathrm{n}=8)$ were made from pork („Pizza šunka“). After collection,the samples were homogenized and stored at $-18{ }^{\circ} \mathrm{C}$ until analysis. All determinations were conducted in triplicate.

\section{Determination of protein and fat content}

Protein content in samples was determined according to the international standards ISO 937:1978 and expressed as $\mathrm{g}$ protein/100 $\mathrm{g}$ sample.

Fat content in samples was determined according to the international standards ISO 1443:1973 and expressed as $\mathrm{g}$ fat $/ 100 \mathrm{~g}$ sample.

\section{Determination of sodium chloride and nitrite content}

Sodium content in the samples was determined according to the international standards ISO 6869:2000. Sodium chloride content was estimated from the content of sodium according to the Serbian Regulation (Serbian Regulation, 19/2017 and 16/2018) and expressed as g sodium chloride/100 g sample.

Residual nitrite content in samples was determined according to the international standards ISO 2918:1975 and expressed as mg nitrite/kg sample.

Results shown in the tables represent mean values of three measurements \pm standard deviation. 


\section{RESULTS AND DISCUSSION}

Protein and fat content $(\mathrm{g} / 100 \mathrm{~g})$ in CM from the Serbian market are shown in Table 1. The protein content in the product type "Pileća prsa" ranged from 12.4 to $17.4 \mathrm{~g} / 100 \mathrm{~g}$ and in the product type "Pizza šunka" ranged from 11.5 to $14.3 \mathrm{~g} / 100 \mathrm{~g}$. The legal limit of protein content according to the Serbian regulation (2015) for this type of products type is minimum $12 \%$. Only one sample from the total of 19 samples did not fulfil the legal requirements, while $74 \%$ of samples had protein content $20 \%$ higher than the legal minimum, $10 \%$ of samples had protein content in the range from $20 \%$ to $40 \%$ higher than the legal minimum and $11 \%$ of samples had $40-60 \%$ higher proteins than the legal minimum which was reported earlier by Delić et al. (2019). The fat content in the "Pileća prsa" product type ranged from 0.92 to $3.84 \mathrm{~g} / 100 \mathrm{~g}$ whereas in the product "Pizza šunka" ranged from 4.61 to 14.4 $\mathrm{g} / 100 \mathrm{~g}$. The statement about high protein and low fat contents in $\mathrm{CM}$ mentioned above has been confirmed for these products from the Serbian market, even though products made from chicken meat ("Pileća prsa") had higher protein and lower fat content than products made from pork meat ("Pizza šunka"). Sodium chloride $(\mathrm{g} / 100 \mathrm{~g})$ and residual nitrite $(\mathrm{mg} / \mathrm{kg})$ contents in the CM samples collected from the Serbian market are shown in Table 2. Sodium chloride content in "Pileća prsa" product ranged from 1.09 to $1.96 \mathrm{~g} / 100 \mathrm{~g}$ whereas in "Pizza šunka" ranged from 1.01 to $1.63 \mathrm{~g} / 100 \mathrm{~g}$. From the presented results it can be seen that $90.91 \%$ of samples "Pileća prsa" had sodium chloride content lower than $1.5 \mathrm{~g} / 100 \mathrm{~g}$, i.e. only one sample $(9.09 \%)$ had sodium chloride content higher than $1.5 \mathrm{~g} / 100 \mathrm{~g}$. For "Pizza šunka" $75 \%$ of samples had sodium chloride content below $1.5 \mathrm{~g} / 100 \mathrm{~g}$. The results obtained in this study were in accordance with the results of Parpia et al., (2018) for sodium chloride-reduced products and were lower than results obtained by Kamenik et al. (2017) and Pretorius \& Schönfeldt (2018) for similar products. According to literature data, the sodium chloride content can be reduced to $1.5-1.7 \%$ without changing the sensory and technological properties of the product (Kamenik et al., 2017). Furthermore, according to Honikel (2008) $1.5 \%$ is sufficient for increasing water binding capacity of proteins, while Feiner (2006) recommends minimal amount of $1.2 \%$ of sodium chloride is meat products needed to the effective activation of proteins. To improve the taste of meat products, $1 \%$ of sodium chloride content is sufficient (Honikel, 2008). In their work, Kamenik et al. (2017) concluded that relationship of sodium chloride content and analysed instrumental and sensory characteristics was not strong; supporting indicates that it is possible to reduce sodium chloride contention in meat products without changing the sensory or textural properties. Even though, the analysed CM samples from the Serbian market had relatively low content of sodium chloride, compared to similar products from the literature, all possibilities for further sodium chloride reduction should be considered. These intentions are firstly guided by the statements of the European Society of Cardiology saying that Serbia is a high risk country with cardio-

Table 1.

Protein and fat content (g/100 g) in the samples of "Pileća prsa" and "Pizza šunka" collected from the Serbian retail market in 2018

\begin{tabular}{|c|c|c|c|c|c|c|c|c|c|c|c|}
\hline \multirow{2}{*}{$\begin{array}{l}\text { Product } \\
\text { Sample }\end{array}$} & \multicolumn{11}{|c|}{ „Pileća prsa“ } \\
\hline & $\mathrm{P} 1$ & $\mathrm{P} 2$ & P3 & $\mathrm{P} 4$ & P5 & P6 & P7 & $\mathrm{P} 8$ & P9 & P10 & P11 \\
\hline \multirow{2}{*}{$\begin{array}{l}\text { Protein } \\
\text { content }\end{array}$} & 14.2 & 13.4 & 12.4 & 14.2 & 15.0 & 12.7 & 13.8 & 15.6 & 17.2 & 17,4 & 14,3 \\
\hline & \pm 0.01 & \pm 0.01 & \pm 0.07 & \pm 0.10 & \pm 0.02 & \pm 0.07 & \pm 0.03 & \pm 0.05 & \pm 0.14 & $\pm 0,08$ & $\pm 0,02$ \\
\hline \multirow{2}{*}{$\begin{array}{c}\text { Fat } \\
\text { content }\end{array}$} & 1.89 & 1.95 & 3.84 & 0.98 & 1.79 & 2.19 & 3.72 & 1.10 & 0.92 & 1,04 & 1,3 \\
\hline & \pm 0.01 & \pm 0.02 & \pm 0.03 & \pm 0.00 & \pm 0.02 & \pm 0.03 & \pm 0.03 & \pm 0.01 & \pm 0.00 & $\pm 0,00$ & $\pm 0,01$ \\
\hline \multirow{2}{*}{$\begin{array}{l}\text { Product } \\
\text { Sample }\end{array}$} & \multicolumn{11}{|c|}{ „Pizza šunka } \\
\hline & $\mathrm{P} 1$ & P3 & $\mathrm{P} 4$ & P5 & P6 & $\mathrm{P} 12$ & P13 & P14 & & & \\
\hline \multirow{2}{*}{$\begin{array}{l}\text { Protein } \\
\text { content }\end{array}$} & 13.3 & 13.2 & 14.3 & 11.5 & 13.0 & 12.2 & 12.7 & 14.0 & & & \\
\hline & \pm 0.10 & \pm 0.08 & \pm 0.01 & \pm 0.04 & \pm 0.02 & \pm 0.00 & \pm 0.03 & \pm 0.05 & & & \\
\hline \multirow{2}{*}{$\begin{array}{c}\text { Fat } \\
\text { content }\end{array}$} & 6.12 & 6.19 & 6.78 & 14.4 & 5.07 & 4.61 & 8.57 & 9.52 & & & \\
\hline & \pm 0.02 & \pm 0.02 & \pm 0.10 & \pm 0.06 & \pm 0.04 & \pm 0.02 & \pm 0.03 & \pm 0.04 & & & \\
\hline
\end{tabular}

Results are given as mean \pm standard deviation $(n=3)$ 
Table 2.

Sodium chloride $(\mathrm{g} / 100 \mathrm{~g})$ and nitrite content $(\mathrm{mg} / \mathrm{kg})$ in the CM samples "Pileća prsa" and Pizza šunka" collected from the Serbian retail market in 2018

\begin{tabular}{|c|c|c|c|c|c|c|c|c|c|c|c|}
\hline \multirow{2}{*}{$\begin{array}{l}\text { Product } \\
\text { Sample }\end{array}$} & \multicolumn{11}{|c|}{ „Pileća prsa“ } \\
\hline & $\mathrm{P} 1$ & $\mathrm{P} 2$ & P3 & $\mathrm{P} 4$ & P5 & P6 & P7 & P8 & P9 & P10 & P11 \\
\hline \multirow{2}{*}{$\begin{array}{l}\text { Sodium } \\
\text { chloride } \\
\text { content }\end{array}$} & 1.45 & 1.21 & 1.45 & 1.96 & 1.30 & 1.40 & 1.35 & 1.31 & 1,18 & 1,17 & 1,09 \\
\hline & \pm 0.05 & \pm 0.02 & \pm 0.05 & \pm 0.03 & \pm 0.03 & \pm 0.03 & \pm 0.05 & \pm 0.04 & $\pm 0,07$ & $\pm 0,03$ & $\pm 0,04$ \\
\hline \multirow{2}{*}{$\begin{array}{l}\text { Nitrite } \\
\text { content }\end{array}$} & 6.60 & 7.74 & 6.51 & 13.51 & 7.74 & 20.7 & 8.43 & 9.00 & 13.9 & 0.62 & 7.28 \\
\hline & \pm 0.07 & \pm 0.10 & \pm 0.04 & \pm 0.09 & \pm 0.02 & \pm 0.06 & \pm 0.10 & \pm 0.06 & $\pm 0,05$ & $\pm 0,03$ & $\pm 0,07$ \\
\hline \multicolumn{5}{|l|}{ Product } & \multicolumn{4}{|c|}{ „Pizza šunka" } & & & \\
\hline Sample & $\mathrm{P} 1$ & P3 & P4 & P5 & P6 & P12 & P13 & P14 & & & \\
\hline \multirow{2}{*}{$\begin{array}{l}\text { Sodium } \\
\text { chloride } \\
\text { content }\end{array}$} & 1.63 & 1.17 & 1.03 & 1.47 & 1.36 & 1.54 & 1.41 & 1.20 & & & \\
\hline & \pm 0.06 & \pm 0.04 & \pm 0.03 & \pm 0.05 & \pm 0.04 & \pm 0.03 & \pm 0.04 & \pm 0.03 & & & \\
\hline \multirow{2}{*}{$\begin{array}{l}\text { Nitrite } \\
\text { content }\end{array}$} & 16.1 & 7.74 & 7.46 & 3.27 & 4.89 & 19.7 & 16.6 & 4.16 & & & \\
\hline & \pm 0.02 & \pm 0.03 & \pm 0.05 & \pm 0.03 & \pm 0.02 & \pm 0.02 & \pm 0.03 & \pm 0.05 & & & \\
\hline
\end{tabular}

Results are given as mean \pm standard deviation $(n=3)$

vascular diseases being the leading causes of mortality (Giga et al., 2017).

Residual nitrite content in the samples of "Pileća prsa" ranged from 0.62 to $20.7 \mathrm{mg} / \mathrm{kg}$ whereas in "Pizza šunka" ranged from 3.27 to $19.2 \mathrm{mg} / \mathrm{kg}$. Currently, the legal limit for added nitrite according to the Serbian Regulation (Serbian Regulation, 53/2018) for this product type is maximum $150 \mathrm{mg} / \mathrm{kg}$. According to the literature data (Honikel, 2008), after thermal treatment of meat products content of added nitrite decreases and around $35 \%$ remain as residual, what indicated that producers did not use a maximum allowed concentration of nitrites during processing. The average nitrite value for the examined samples was $9.54 \mathrm{mg} / \mathrm{kg}$ which is in accordance with literature data for similar meat products (Bajčić et al., 2018; Hamid et al., 2020).

\section{CONCLUSIONS}

The analysed samples of CM collected from the Serbian retail market, produced by 14 most abundant meat processors, contained high protein and low fat contents. The products made from chicken meat ("Pileća prsa") had higher protein and lower fat content than the products made from pork meat ("Pizza šunka").

Even though the examined samples had relatively low content of sodium chloride ( $84 \%$ of samples were below $1.5 \mathrm{~g} / 100 \mathrm{~g}$ ) all possibilities for further sodium chloride reduction should be considered, since Serbia is a country with high prevalence of cardiovascular diseases.
Also, the residual nitrite content was in the range from 0.62 to $20.7 \mathrm{mg} / \mathrm{kg}$, which means that all samples were below the required limits. According to the results obtained in this study, children and consumers on special dietary regimes are free to consume Serbian meat products in the type of CM considering the content of protein and fat, as well as from sodium chloride and nitrite content. All examined quality issues were in accordance with the legal requirements, and low sodium chloride content was in accordance with WHO recom-mendation for a daily average consumption of $<5-6 \mathrm{~g}$ of $\mathrm{NaCl}$ or $<2-2.4 \mathrm{~g}$ of $\mathrm{Na}$.

\section{ACKNOWLEDGEMENTS}

This work was financially supported by the Ministry of Education, Science and Technological Development of the Republic of Serbia under the Agreements on the Implementation and Financing of Research (Nos. 451-03$68 / 2020-14 / 200222$ and 451-03-68/202014/200134).

\section{REFERENCES}

Bajčič, A., Petronijević, R., Katanić, N., Trbović, D., Betić, N., Nikolić, A., \& Milojević, L. (2018). Evaluation of the content and safety of nitrite utilisation in meat products in Serbia in the period 2016-2018. Meat Technology, 59, 102-109. https://doi.org/10.18485/meattech.2018.59.2.4

de Barros Silva Haddad, G., Rocha Moura, A.P., Rogério Fontesa, P., Viana da Cunhab, S.F., Souza Ramosa, A.L., \& Mendes Ramosa, E. (2018). The effects of sodium chloride and PSE meat on restructured cured-smoked pork loin quality: A 
response surface methodology study. Meat Science, 137, 191-200. https://doi.org/10.1016/j.meatsci.2017.11.030

Delić, J., Peulić, T., Ikonić, P., Jokanović, M., Škaljac, S., Ivić, M., \& Mastilović, J. (2019). Quality of meat products from the Serbian market in terms of protein content. In Proceedings of the $60^{\text {th }}$ International Meat Industry Conference MEATCON (pp. 1-5). Kopaonik, Serbia.

Desmond. E. (2006) Reducing salt: A challenge for the meat industry. Meat Science, 74, 188-196. https://doi.org/10.1016/j.meatsci.2006.04.014

Doyle, M.E., \& Glass, K.A. (2010). Sodium reduction and its effect on food safety, food quality, and human health. Comprehensive Reviews in Food Science and Food Safety, 9, 44-56.

https://doi.org/10.1111/j.1541-4337.2009.00096.x

EFSA. (2009). Review of labelling reference intake values- Scientific Opinion of the Panel on Dietetic Products, Nutrition and Allergies on a request from the Commission related to the review of labelling reference intake values for selected nutritional elements [1]. The EFSA Journal, 1008, 1-14. https://doi.org/10.2903/j.efsa.2009.1008

EFSA. (2010). Statement on nitrites in meat products. The EFSA Journal, 8, 1538-1549. https://doi.org/10.2903/j.efsa.2010.1538

European Commission. (2011). Regulation (EC) No. $1129 / 2011$ of the European Parliament and of the council of 12 November 2011 amending annex II to regulation (EC) No. 1333/2008 of the European Parliament and of the council by establishing a union list of food additives. The Official Journal of the European Union, L295, 1.

Giga, V., Beleslin, B., \& Djordjevic-Dikic, A. (2017). Country report Serbia - April 2017 prepared for the European Society of Cardiology. Available from:

https://www.escardio.org/static-

file/Escardio/Subspecialty/EAPC/Country\%20of\% 20the $\% 20$ month/Documents/serbia-country-ofthe-month-full-report.pdf

Gilchrist, M., Winyard, P.G., \& Benjamin, N. (2010). Dietary nitrate-good or bad? Nitric Oxide, 22, 104-109. https://doi.org/10.1016/j.niox.2009.10.005

Godfray, H.C.J., Aveyard, P., Garnett, T., Hall, J.W., Key, T.J., Lorimer, J., Pierrehumbert, R.T., Scarborough, P., Springmann, M., \& Jebb, S.A. (2018). Meat consumption, health, and the environment. Science, 361, eaam5324. http://dx.doi.org/10.1126/science.aam5324

Hamid, N.F.H.J., Khan, M.M., \& Lim, L.H. (2020). Assessment of nitrate, nitrite and chloride in selected cured meat products and their exposure to school children in Brunei Darussalam. Journal of Food Composition and Analysis, 91, 103520. https://doi.org/10.1016/j.jfca.2020.103520

ISO 1443:1973. (1973). Determination of total fat content. Meat and meat products. Geneva, Switzerland: International Organization for Standardization.

ISO 2918:1975. (1975). Determination of nitrite content.
Meat and meat products. Geneva, Switzerland: International Organization for Standardization.

ISO 6869:2000. (2000). Determination of the contents of calcium, copper, iron, magnesium, manganese, potassium, sodium and zinc - Method using atomic absorption spectrometry. Geneva, Switzerland: International Organization for Standardization.

ISO 937:1978. (1978). Meat and meat products. Determination of nitrogen content. Geneva, Switzerland: International Organization for Standardization.

Kameník, J., Saláková, A., Vyskočilová, V., Pechová, A., \& Haruštiaková, D. (2017). Salt, sodium chloride or sodium? Content and relationship with chemical, instrumental and sensory attributes in cooked meat products. Meat Science, 131, 196-202. http://dx.doi.org/10.1016/j.meatsci.2017.05.010

Lawrie, R. A., \& Ledward, D. A. (2006). Lawrie's meat science (7th ed.). Cambridge, England: Woodhead Publishing Ltd. and CRC Press LLC.

Matthews, K., \& Strong, M. (2005). Salt - Its role in meat products and the industry's action plan to reduce it. Nutrition Bulletin, 30, 55-61. https://doi.org/10.1111/j.1467-3010.2005.00469.x

Parpia, A.S., Goldstein, M.B., Arcand, J., Cho, F., R. L'Abbé, M., \& Darling, P.B. (2018). Sodium-reduced meat and poultry products contain a significant amount of potassium from food additives. Journal of the Academy of Nutrition and Dietetics, $118,878-885$. https://doi.org/10.1016/j.jand.2017.10.025

Pretorius, B., \& Schönfeldt, H.C. (2018) The contribution of processed pork meat products to total salt intake in the diet. Food Chemistry, 238, 139-145. https://doi.org/10.1016/j.foodchem.2016.11.078

Rede, R. R., \& Petrović, S. Lj. (1997). Tehnologija mesa i nauka o mesu. Tehnološki fakultet, Novi Sad.

Sebranek, J. G. (2009). Basic curing ingredients. Ingredients in meat products. New York, NY: Springer.

Serbian Regulations 19/2017, 16/2018. (2017). Pravilnik o deklarisanju, označavanju i reklamirnaju hrane. Službeni glasnik RS, 19/2017, Službeni glasnik RS, 16/2018.

Serbian Regulation 53/2018. (2018). Pravilnik o prehrambenim aditivima. Službeni glasnik RS, 53 .

Serbian Regulations 94/2015, 104/2015, 19/2017. (2015). Pravilnik o kvalitetu usitnjenog mesa, poluproizvoda od mesa i proizvoda od mesa. Službeni glasnik RS, 94/2015, Službeni glasnik RS, 104/2015, Službeni glasnik RS, 19/2017.

Sun, Y. C., Mi, J. C., Lee, S. J., Shin, J. H., \& Sung, N. J. (2007). N-nitrosamine inhibition by strawberry, garlic, kale, and the effects of nitrite-scavenging and $\mathrm{N}$-nitrosamine formation by functional compounds in strawberry and garlic. Food Control, 18, 485-491. https://doi.org/10.1016/j.foodcont.2005.12.006

Šarčević, D., Lilić, S., Djordjević, V., Milicević, D., Vranić, D., Lakicević, B., \& Milijasević, M. (2011). The role of consumer's perception and attitude in purchasing of meat and meat products. Meat Technology, 52, 283-290. 


\section{САДРЖАЈ НАТРИЈУМ ХЛОРИДА И НИТРИТА У КОНЗЕРВАМА ОД МЕСА У КОМАДИМА НА ТРЖИШТУ РЕПУБЛИКЕ СРБИЈЕ}

Татјана А. Пеулић*1, Предраг М. Иконић ${ }^{1}$, Марија Р. Јокановић ${ }^{2}$, Јована Д. Делић ${ }^{1}$, Јасмина М Губић $^{1}$, Снежана Б. Шкаљац ${ }^{2}$, Јасна С. Мастиловић ${ }^{1}$

${ }^{1}$ Универзитет у Новом Саду, Научни институт за прехрамбене технологије у Новом Саду, 21000 Нови Сад, Булевар цара Лазара бр. 1, Србија

${ }^{2}$ Универзитет у Новом Саду, Технолошки факултет, 21000 Нови Сад, Булевар цара Лазара бр. 1, Србија

Сажетак: Конзерве од меса у комадима су производи од меса које у највећој мери конзумирају деца и потрошачи са специјалним захтевима у исхрани, због виског садржаја протеина и ниског садржаја масти. Стога је циљ овог рада био да се у овој групи производа од меса испита садржај натријум хлорида и нитрита у укупно 19 узорака прикупљених од 14 најзаступњенијих произвођача на тржишту Републике Србије. Чињеница да конзерве од меса у комадима имају висок садржај протеина и низак садржај масти, потврђена је у овим истраживањима. Садржај протеина у узорцима Пилећих прса кретао се у интервалу од 12,4 до 17,4 г/100 г, а масти од 0,92 до 3,84 г/100 г док се у узорцима Пица шунке садржај протеина кретао у интервалу од 11,5 до 14,3 г/100 г, а масти од 4,61 до 14,4 г/100 г. У 90,91\% узорака „Пилећих прса“ садржај натријум хлорида био је нижи од 1,5\%, док је исти резултат добијен за 75\% узорака Пица шунке. Резидуални садржај нитрита се у узорцима Пилећих прса кретао у интервалу од 0,62 до 20,7 мг/кг, док се у узорцима Пица шунке кретао у интервалу од 3,27 до 19,2 мг/кг. Утврђене вредности нитрита у свим узорцима су испод прописаних граница. На основу свих резултата добијених у овом истраживању може се закључити да производе декларисане као конзерва од меса у комадима са тржишта Републике Србије слободно могу конзумирати све групе потрошача, како са аспекта саржаја протеина и масти, тако и са аспекта садржаја натријум хлорида и натријум нитрита.

Кључне речи: производи од меса, пилеће месо, свињско месо, садржај протеина, садржај масти, безбедност, тржиште производа од меса Србије

Received: 30 October 2020/Received in revised form: 03 December 2020/ Accepted: 10 December 2020

Available online: December 2020

This is an open-access article under the CC BY license (http://creativecommons.org/licenses/by/3.0). 